Historic, Archive Document

Do not assume content reflects current scientific knowledge, policies, or practices. 



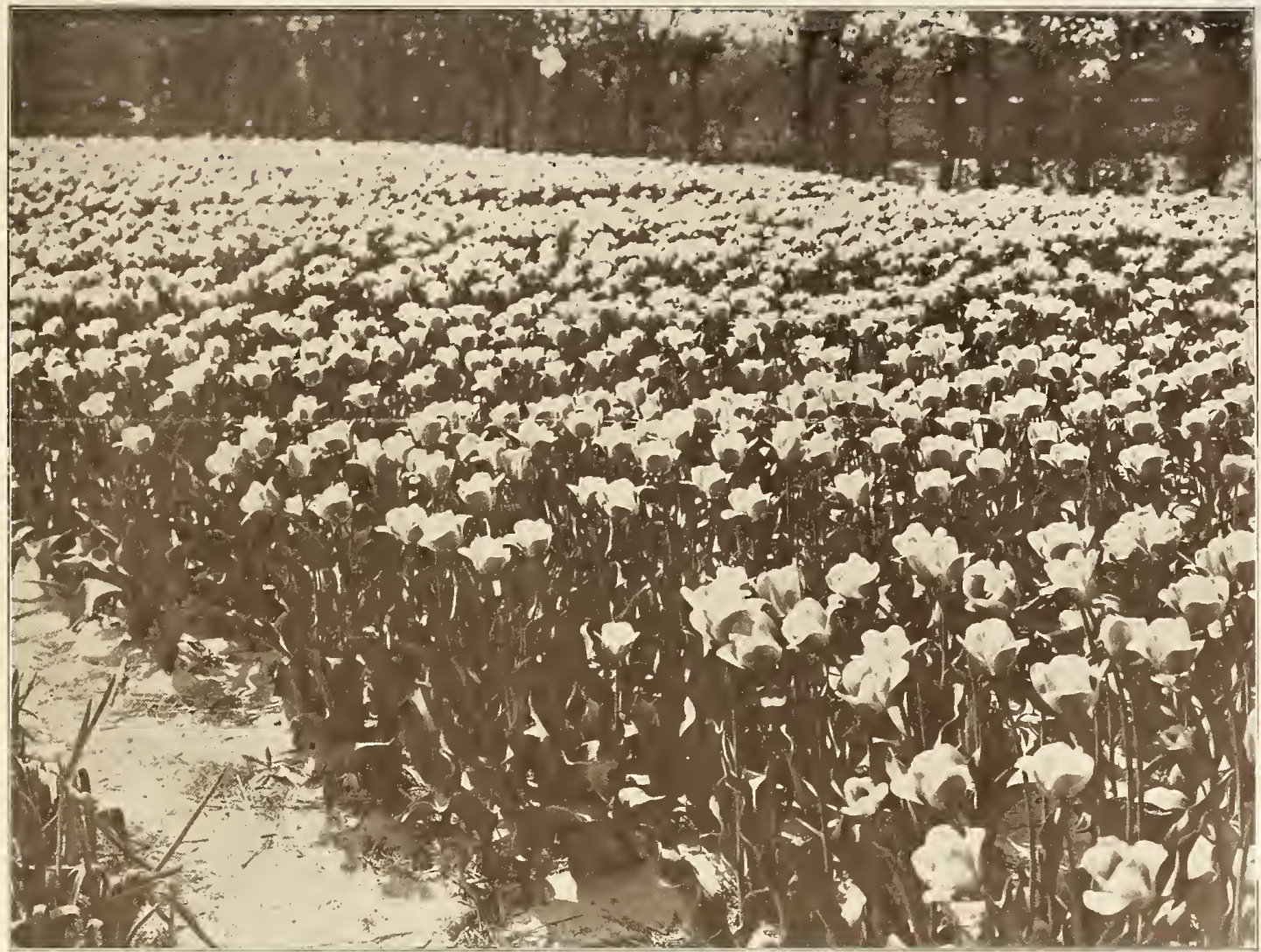

On the farm in Holland where Farr's Tulip bulbs are grown. For 15 years our supply has come from one grower

\section{JUST GARDENS}

T DOES not matter where they grow;

1 Their loveliness will be

A place where lonely souls may go

In lands of memory.

They may be stately, with a dial

To catch the sun's warm shine-

They may be tender as a smile,

Or as a Valentine.

They may show just a touch of green

Against some city wall;

And yet, to wistful hearts, they mean

Youth's wonder, and life's aII.

Just gardens, rising from the sod

Like laughter, swect in tone,

Like anthems, giving back to God

The dearest thing we own.

It does not matter, very much,

The spot in which they grow-

For we come closer, by their touch,

To One, Whose love we know.

- Miargaret E. Sangster in Cbristian Herald

\section{GREATLY PLEASED WITH} NARCISSI AND LILACS

March 9, 1927

BERTRAND H. FARR,

Weiser Park, $\mathrm{P}$.

Last fall I bought from you the "Wordsworth" collection of Narcissi. I wish you could see the gorgeous display of the Narcissi I have in bloom now. I think there have been from two to four flowers from every one of the Barri conspicuus bulbs, and the Emperor and Rugulosus are very large; a
good many of them have two flowers from good many of them have two flowers from one bulb. The Poets and Empress have
not bloomed, but are budding. Some of my not bloomed, but are budding. Some of my Barrii conspicuus flowers are 3 to 4 inches
across. I am highly pleased with them all across. I am highly pleased with the
and will have another order this fall.

and will have another ord er this fall. at the same time, have fine clusters of buds, some of them far enough advanced to be showing color. I am very anxious to see them. You know our springs are so early that all these flowers are gone here bafore they bloom with you.

Do you have a spring-blooming bulb called Leucojum vernum, or Spring Snowflake a white bell-shaped flower with light green spots on the petals? I want to get some and have never found them in but one catalogue and that was misplaced so I don't know whose it was. When would be the best time to buy them? Very truly yours,

MRS. HARRY E. KELLEY

Park Hill, 2122 S. W St., Ft. Smith, Ark.
Holland Bulb Essentials

Dutch bulbs are extremely modest in their cultural dcmands. Many of the old rulcs for bulb growing would lead an ordinary gardener to infer that success is concealed from ordinary mortals, and that certain rites must be followed if even ordinary results are to be secured. Not so, but there are certain simple cautions to be observed which will assure stronger growth and larger blooms.

\section{What to Do in Fall}

1. Light, rich, and well-drained soil is the best for bulbs. Add sand or ashes to clay soil, or clay to sandy soil. Do not use fresh manure. Bone-meal and sheepmanure are good. Prepare the beds before bulbs arrive.

2. Uniform depth of planting is essentia for bedding purposes. Irregular depth o planting produces irregular bloom. Setting the bulbs in trenches, made with a hoe, is a good method.

3. Most important-be sure to plant to correct depth. Three times the dianeter of the bulb is a safe and easy rule.

4. Do not apply top cover until ground is permanently frozen.

5. Ask for our circular on indoò forcing (Concluded on page 3 ) aturis 


\section{Tulips}

The great variety of dazzling Tulips, in every conceivable color combination, makes them the most popular of the spring-flowering bulbs. By planting bulbs of the different classes, a display of bloom may be had for several weeks, beginning first with the early-flowering section and ending with the Darwins and Breeders. Even a dozen bulbs will make a brilliant corner in the garden. The test of quality in Tulips is solidity rather than size of the bulbs. We import the best grown.

\section{SINGLE EARLY TULIPS}

All varieties in this list may be used with equal success for bedding or for forcing. Stems 10 to 15 inches high. Bloom in late April. Plant 4 to 5 inches deep, 5 to 6 inches apart.

Six or more bulbs of one variety at the dozen rate; 25 or more at the $I 00$ rate. Not less tban 6 bulbs of one kind sold.

Belle Alliance. 12". Clear Doz. 100 deep scarlet $\$ 070 \quad \$ 500$

Chrysolora. 13". Large; pure golden yellow.

$70 \quad 500$

Coleur de Cardinal. 13".

Large; rich crimson; strong stem.

Duchesse de Parma. 13". Showy orange-red ...... $75 \quad 550$

Flamingo. 13". Large; beautiful pink and white. . $75 \quad 550$

GENERAL DE WET. 16".

Brightest and best orange. $200 \quad 1500$

Keizerskroon. 16". Popular; red and yellow.... $95 \quad 700$

PinK BEautY. 13". Bright cherry-pink ... ' Tall; deep

Rising Sun. 16

"Wite Hawk. 13". White. 80600

Superfine Mixture. From choice and distinct varieties of similar height and season. Top-size bulbs. 60 cts. per doz., $\$ 3.50$ per $100, \$ 32$ per 1,000 .

\section{COTTAGE TULIPS}

(Single or May-flowering)

Cottage Tulips are fine for naturalizing in permanent borders. They come up and bloom year after year. When alternated with Single Earlies, the blooming season is prolonged. Height 18 inches. Bloom May 15. Originated in England among the English cottages.

Six or more bulbs of one variety at the dozen rate; 25 or more at the 100 rate. Not less than 6 of one kind sold.

Ellen Willmott. 25". Large; soft yellow.....\$0 $70 \quad \$ 450$

GESNERIANA LUTEA. 26"

Sweet-scented; lemon-yellow......... .

$70 \quad 400$

Gesneriana major (Spathulata). 20". Crimson-scarlet.

Glare of THE Garden. 21". Shapely; vivid scarlet

Golden Crown. 23". Yellow, with red edges.

Grenadier. 24". Brilliant orange-red; large

INGLESCOMBE PINK. 2 $25^{\prime \prime}$. Soft rose, flushed salmon $70 \quad 400$

$75 \quad 500$

$70 \quad 4 \quad 50$

70500
INglescombe Scarlet. 18". Doz. 100 Large scarlet flowers..... \$0 $65 \$ 400$

INCLESCOMBE Yellow (YeI-

low Darwins). 23". Large: globular yellow. Used with Darwin combinations

John Ruskin. 18". Bronzerose and yellow

Moonlight. 24". Ovalshaped; canary-yellow.

Orange King. 22". Deep orange, with delicate rose. .

Picotee (Maiden's Blush).

$20^{\prime \prime}$. White, tipped rose $\quad 70 \quad 400$

Superfine Mixture. 60 cts. per doz., $\$ 3.50$ per $100, \$ 32$ per 1,000 .

\section{DOUBLE EARLY TULIPS}

With few exceptions, Double Tulips should be used for forcing and bedding only. The flowers are very durable, and as they open slightly later than other Tulips, they prolong the flowering period. Stems 12 to 15 inches high. Bloom during late April and are remindful of peonies. Alternate rows of Single Early and Double Tulips are very effective.

Six or more of one variety at the dozen rate; 25 or more at the 100 rate. Not less than 6 of one kind sold.

Couronne D'Or (Crown of

Gold). 11". Yellow and Doz. 100 orange........... \$0 $70 \quad \$ 500$

Murillo. 13". Light pink. $70 \quad 450$ MYSTERY OF INDIA.

12". New. Terra-cotta

with salmon.......... $150 \quad 1000$

ScHOONOORD. 13". Large;

pure white.......... $70 \quad 500$

Tournesol. 11". "Double Keizerskroon." Red and yellow $\$ 3.50$ per $100, \$ 32$ per 1,000 .

\section{DARWIN TULIPS}

Darwin Tulips are highly recommended for massing in shrubbery and for providing contrasting colors in the spring garden. Groups of twenty-five to fifty bulbs of one color produce striking and beautiful effects. In form, the cupped blooms are entirely distinct from all other classes of Tulips; they are unusually large and borne on long stems. Bulbs may be forced if brought to the heat not earlier than January. Garden bloom, May 15.

Six or more bulbs of one variety at the dozen rate; 25 or more at the 100 rate. Not less than 6 of one kind sold.

Baron de la TONNAYE. 26". Doz. 100 Rose, margined blush..... \$0 $65 \$ \$ 375$

Bartigon. 26". Earliest; very Iarge; fiery red.

CHANT DE CYGNE. 23". Large; light cherry-red.

Clara Butt, 22". Delicate saImon-pink. Best.

$275 \quad 2000$

Dream. 24". Heliotrope, shaded violet.

Edmee. 25". Cherry-rose, edged lighter.

Farncombe SANDERS. $255^{\prime \prime}$ Immense; brilliant scarlet .

JACOB MARIS. 26". Large; mahogany-red . 24". Tall; $65 \quad 375$

King Harold. 24".

Tall; la Tulipe Noire. "The Black Tulip."

Loveliness. 23". Soft, rosy carmine.

Mme. Krelage. 28". Bright lilac-rose.

Philippe de Cominases. 24". Deep purple

Pride of HaARlem. $30^{\prime \prime}$. Tall; violet-rose

REV. D'OMIBRAIN. 26". Giant; darkest red.

Rev. EwBank. 23". Soft Iavender-violet. . . . . . . .

Whistler, 24". Mlarooncrimson.............

White Queen. 24". Rose, fading to white.........

IVilliam Copland. 24". Large; lilac. Early. $23^{\prime \prime}$ Doz. 160 $\$ 080 \$ 600$ (See Inglescombe Yellow.) One of the few popularpriced yellow Tulips which bloom and can be used with Darwins. True Darwin yellows are as scarce as true yellow peonies.

70400

ZuLu. 27". Velvety purpleblack. Superfine Mixture. 60 cts. per doz., $\$ 3.50$ per $100, \$ 32$ per 1,000 .

\section{BREEDER TULIPS}

Breeder Tulips are the unbroken forms of the old florists' Tulips. The blooms strongly resemble the Darwins, excepting that they havc an entirely different range of color, comprising artistic tones of bronze, terra-cotta, orange, and brown. Breeder Tulips are May-flowering, producing blooms of enormous size, and because they are vigorous growers are valuable for the garden. We have taken great pains to select only the choicest varieties, and recommend all of them to anyone who wishes something especially fire. In height and blooming season they are practically identical with $\mathrm{L}$ arwins and can well be combined with them.

Six or more bulbs of one rariety at the dozen rate; 25 or more at the 100 rate. Not less than 6 of one kind sold.

BACCHUS. 33". Bluest of Doz. 100 all Tulips. Giant.

$\$ 175 \$ 1200$

Bronze KING. 28". Bronzeyellow

Cardinal Maning. 26". Wine-red, flushed brown.

Dom Pedro. 30". Coffeebrown, edged golden brown $150 \quad 1000$

Godet Parfait. 30". Deep purple, white base, blue halo

$80 \quad 600$

Grand MaItre. 24". Dark purple.

J AUNE D'EEUF. 24". Apricot, edged yellow

80.600

$80 \quad 600$

LOUIS XIV. $28^{\prime \prime}$. Purple, bronze, and brown. . . . . .

MEDEA. 18". Large; salmon-carmine

Mon Tresor. 25". Distinct; carmine-red

Prof. Schotel. 23". Large; pointed petals; blue

ROSE DEs DAMES. 23". Rosi red, touched orange.

$150 \quad 1000$

$80 \quad 600$

95700

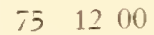

$80 \quad 600$

$80 \quad 600$

$80 \quad 600$

$80 \quad 600$

Superfine Míxture. $60 \mathrm{cts}$. per doz., $\$ 3.50$ per 100 , $\$ 32$ per 1,000 . 
HOLLAND BULB ESSENTIALS, concluded if cut-flowers for winter are desired for the house.

6. Place orders early so as to be in line for early fall shipment, which is when bulbs arrive from Holland.

\section{What to Do in Spring}

1. Do not remove top cover until danger of spring frosts has passed.

2. Keep weeded and cultivated until blooms appear.

3. Cut all blooms before seed-pods appear. Do not cut foliage until wilted.

4. If desired, lift, clean, cure, and store bulbs in dry, cool place until fall.

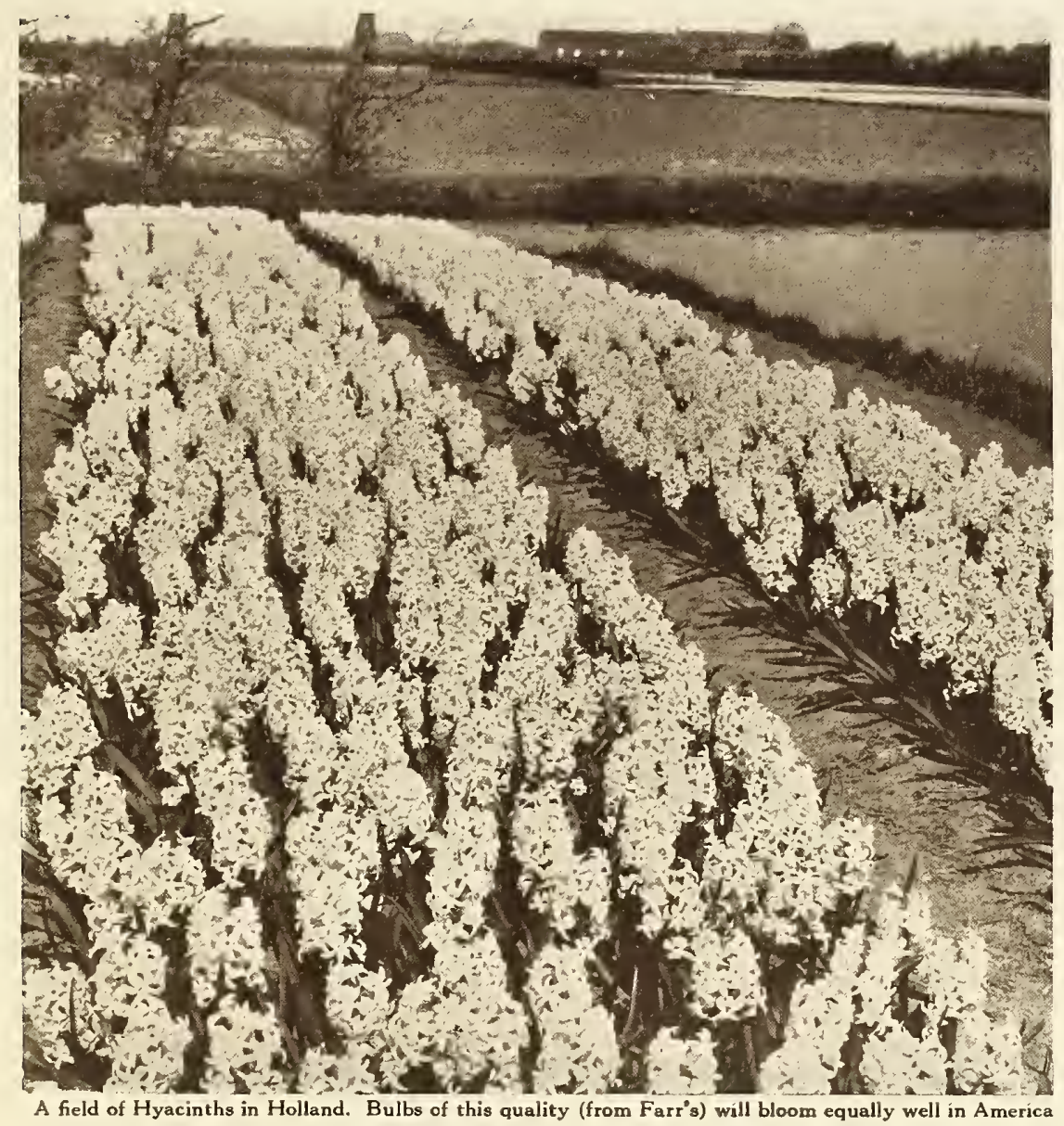

\section{Hyacinths}

Culture is similar to other bulbs. Plant 6 inches apart and cover with 4 inches soil. Setting the bulbs on a layer of sand improves the bloom. They are best in beds and other formal arrangements. A most popular indoor plant; anyone can handle them. Unexcelled for fragrance.

We specialize in the best grade Hyacinths. The stock for 1927 is of 18-19 centimeter circumference, second in size only to the very largest bulbs obtainable. If the blooms produced are not of the largest you bave ever seen, your money will be refunded.
All named Hyacinths, 30 cts. each, $\$ 3$ per doz., $\$ 20$ per 100

Single Red and Rose

General De Wet. Large; soft pink. QueEn of THE Pinks. Bright rosy pink. Roi Des Belges. Dark red.

\section{Single Light and Dark Blue}

Enchantress. Porcelain-blue.

Grand Maitre. Compact; sky-blue.

King of the Blues. Late; rich dark blue.

\section{Single Yellow}

Yellow Hyacinth bulbs are small. Yellow Hammer. Pure bright yellow King of the Yellows. Deep yellow. 


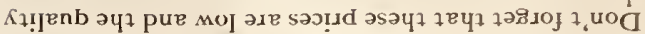

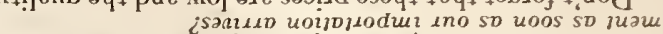

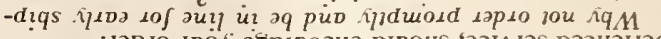

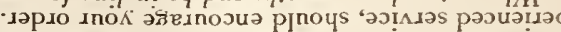

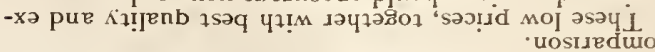

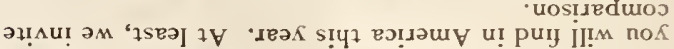

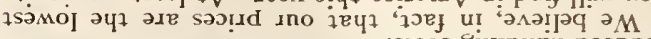
"sisoo siulipuey paonpas

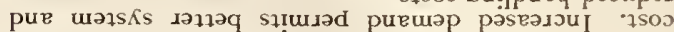

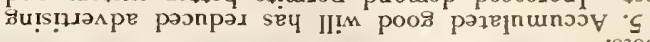

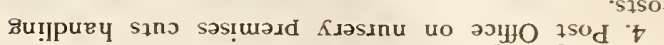
אajenb jensnu

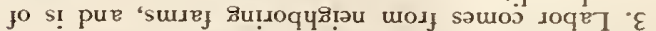

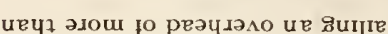

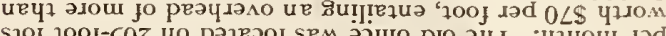

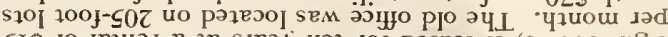

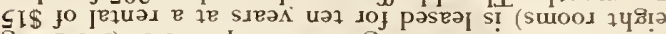

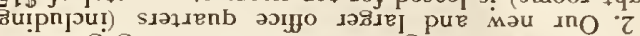

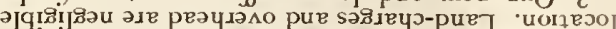
Plo ay

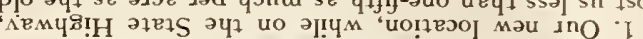

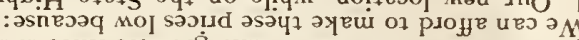

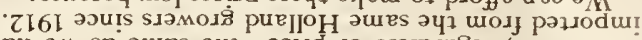

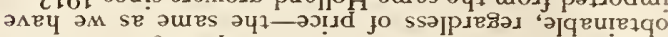

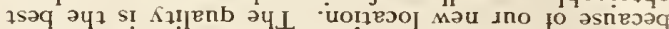

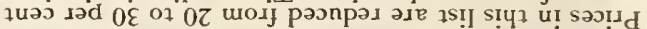

\section{Miscellaneous Bulbs}

(For the Distinctive and Unusual)

The Federal Quarantine has been temporarily lifted on a number of old-time favorites for the spring bulb-garden. The most desirable varieties are here included.

Chlonodoxa (Glory-of-the-Snow). An almost necessary companion to the Crocuses and snowdrops. Easily naturalized and comes up each year. Dark blue flowers with white eye. 6 to 10 blooms on a stem 4 to 6 inches high. Splendid for borders and rockeries. 50 c. per doz., $\$ 2.50$ per $100, \$ 22$ per 1,000 .

LiLiUM CANDIDUM (Madonna Lily). Very fragrant, pure white, trumpet-shaped flowers, $31 / 2$ to 5 inches long, borne horizontally, 6 to 25 in a head, on tall, erect, leafy stems 3 to 4 feet high, during late June and July, $50 \mathrm{cts}$. each; 5 or more at 45 c. each; 25 or more at 35c. ea.

REGALe (L. myriopbyllum). A magnificent Lily from western China, with very large, trumpet-shaped flowers of waxy white, shaded pink, tinged with canaryvellow at the base of the petals. Height 4 to $5 \mathrm{ft}$. Blooming-size bulbs, $75 \mathrm{cts}$. each; 5 or more at $60 \mathrm{cts}$. each; 25 at $50 \mathrm{cts}$. each.

Lily-OF-THE-VAlley (Convallaria majalis). Strong clumps, 5 or more at $30 \mathrm{cts}$. each; 25 or more at 25 cts. each. Not less than 5 sold.

Muscari botryoides, Heavenly Blue. Dainty Sky-blue flowers. Lovely in masses. 50 cts. per doz., $\$ 2.50$ per 100 , $\$ 22$ per 1,000 .

Scilla sibirica. Pretty sprays of rich blue flowers. Suitable for naturalizing or indoor forcing. Culture the same as crocuses. 65 cts. per doz., $\$ 4.50$ per $100, \$ 40$ per 1,000

Siowdrops, Single. The very first spring bloomers. Should be planted liberally. Large, white blooms. $50 \mathrm{cts}$ per doz., $\$ 2.50$ per $100, \$ 22$ per 1,000 .

Swownrops, Double. Large, double, white blooms. 65 cts. per doz. \$4 per $100, \$ 35$ per 1,000 .

\section{Weiser Park Bulb Collections}

In keeping with economies and lowered overhead, effected at our new location, it is possible to offer the following collections at very low prices.

Coax spring into your 1928 garden with any or all of these collections. Make your garden a display spot for yourself and the community.

\section{Collection A}

12 Mixed Narcissi

12 Named Single Early Tulips.

$\$ 093$

12 Named Darwin Tulips

12 Named Breeder Tulips.

12 Named Cottage Tulips.

. 70

25 . Mixed Crocuses.............. 50

25 Snowdrops................ 88

6 Assorted Hyacinths.......... . $\frac{1}{\$ 7} \frac{50}{33}$

The Complete Collection for $\$ 5$ Without Hyacinths for $\$ 4$

Our selection of varieties listed in this issue of Better Plants.)

\section{Collection B}

18 Mixed Narcissi.

18 Single Early Tulips in 3 vars.

18 Darwin Tulips in 3 varieties.

18 Breeder Tulips in 3 varieties.

18 Cottage Tulips in 3 varieties

18 Double Early Tulips

50 Mixed Crocuses.

10 Assorted Hyacinths

\$1 25

105

105

105

105

105

100

250

The Complete Collection for $\$ 7.50$

Without Hyacinths for \$5

(Our selection of varieties listed in this issue of Better Plants.

Instructions and Terms for Ordering

On all orders for Holland bulbs mailed to us before July 1, 1927, a discount of 10 per cent is allowed. An additional 2 per cent will be allowed on orders accompanied by cash.

Quantity Rates, Unless otherwise specifred, less than 6 bulbs of one variety will not be supplied. The dozen rate is

\section{Collection $\mathrm{C}$}

30 Mlixed Narcissi............. \$2 10 30 Single Early. Tulips in 3 varieties 175 30 Darwin Tulips in 3 varieties.... 1 T

30 Breeder Tulips in 3 varieties... 175

30 Cottage Tulips in 3 varieties.... 1 ij

30 Double Early Tulips in 3 rars.. 173

50 Mixed Crocuses............. 100

12 Assorted Hyacinths.......... 300

The Complete Collection for $\$ 11$

11 ithout Hyacinths for $\$ 7 . \overline{0}$.

Double these quantities and varieties for $\$ 20$. Without Hyacinths, $\$ 14$

Our selection of varieties listed in this issue of Better PlaNts.)

Farr's "Wordsworth" Collection of Narcissi

"A bost of golden daffodils

Fluttering and dancing in the breeze."

1. Empress.

Doz.

2. EMPEROR

3. Golden Spur

173

4. Von Sion

5. Sir II ATKINS.

6. Poeticus

175

The varieties include Single Large Trumpet, Single Medium, Double and Poet's Narcissi. The price per dozen is indicated, but as a collection we will sell

One dozen of each variety ( 72 bulbs, value $\$ 10$ ) for $\$ 8, \mathbf{f} . \mathbf{o} . \mathbf{b}$. our nursery. Half-dozen of each for \$4.25. Two dozen of each for $\$ 15$.

No early order discount on Collections. Prices $\int . a . b$. our station. A discount of 2 per cent is allowed for casb witb order.

applicable on 6 or more bulbs of one va riety; the 100 rate on 25 or more bulbs of one variety.

Prices are F. O. B. Our Station Shipments are best made by express. If parcel post is necessary, charges are billec at actual postage, plus 12 cts. to partly cover special packing details and service involved. 